\title{
Dielectric properties of alumina ceramics for fusion applications
}

\section{Darío Cruz,}

\section{Rafael Vila}

CIEMAT - National Fusion Laboratory,

Avda. Complutense 40,

28040 Madrid, Spain

E-mail:darioandres.cruz@ciemat.es

\section{Begoña Gómez-Ferrer}

Université et INSA de Rouen, Avenue de l'Université BP12, 76801 Rouen, France

E-mail: begonia.gomez-ferrer@univ-rouen.fr
The insulating materials for radio frequency (RF) windows and different antenna supports for heating systems and some diagnostics are still an unresolved issue in future fusion machines such as DEMO. Alumina ceramic $\left(\mathrm{Al}_{2} \mathrm{O}_{3}\right)$ is one of the main candidate materials for these systems. The dielectric properties, such as electrical permittivity $(\varepsilon)$ and loss $\operatorname{tangent}(\tan \delta)$, determine its power losses. Therefore, $\tan \delta$ values need to be low, between $10^{-6}$ and $10^{-3}$ depending on the application. However, due to the crucial role of the manufacturing process in determining its final dielectric properties, there is the need to undertake a joint effort with the industry in order to validate a standard manufacturing route that ensures a supply of ceramic material with homogeneous and standardized dielectric properties for future fusion machines.

In DEMO, these ceramic materials will be operated under extreme conditions. They will be exposed to considerable levels of neutron irradiation. Radiation Induced Conductivity (RIC) and Radiation Induced Electrical Degradation (RIED) are phenomena that influence notoriously on the dielectric performance of these materials. Therefore, their optimum properties must be tested under relevant irradiation conditions. Hence, it is important to accurately characterize their dielectric properties before irradiation to be able to compare them with the future post neutron irradiation results. Furthermore, other types of radiation such as beta and gamma are also used in the irradiation scheme to provide more information on the variation of dielectric properties of ceramics due to radiation effects.

In this work, loss tangent and permittivity values of some pre-irradiated candidate materials will be presented as well as the measuring techniques used at CIEMAT. These techniques have the advantage of covering a very broad range of frequencies required for alumina applications in fusion (from $\mathrm{kHz}$ to $\mathrm{GHz}$ ) and giving the best accuracy for very low losses.

Keywords: fusion, DEMO, ceramics, dielectric properties, pre-irradiation 


\section{INTRODUCTION}

There are several material issues that need to be addressed before the construction of future fusion reactors such a DEMO. In particular, materials chosen for radio frequency (RF) windows and different antenna and diagnostics supports, as well as insulators for the heating systems are not still fully defined. The systems in which the materials are going to be used operate in three main frequency ranges related to the main heating systems: $40-80 \mathrm{MHz}$ for Ion Cyclotron Heating, 1-15 GHz for Lower Hybrid Current Drive, and 100-250 GHz for Electron Cyclotron Heating. Some of the diagnostics will also require insulators that work at lower frequencies. The dielectric properties, such as electrical permittivity $(\varepsilon)$ and loss tangent $(\tan \delta)$, determine the power losses in the materials. The losses would produce high temperature gradients that could cause material fracture due to mechanical stress. Mechanical and thermal properties need to be studied as well; however, in this case, the main parameter to be considered is the dielectric loss. Therefore, the materials should have low $\varepsilon$, very low $\tan \delta$ values, between $10^{-6}$ and $10^{-3}$ depending on the application, high mechanical strength, high thermal conductivity and radiation resistance. Alumina ceramics is one of the candidate materials that has been studied more extensively [1-4].

Unfortunately, there is not enough information available about the dielectric properties of different alumina grades with respect to the frequency and their dependence on the microstructure and impurity contents. Different alumina types coming from different producers have been studied but a reference material that can be used for the future fusion machines has not yet been found. However, this is not an easy task because the dielectric properties of the alumina ceramics currently vary in an uncontrolled way with different manufacturing processes and are extremely sensitive to fabrication conditions. Therefore, the involvement of the ceramic industry is crucial because there is the need to validate a standard manufacturing route that ensures a supply of ceramic material with homogeneous and standardized dielectric properties for the fusion machines.

\section{RIC and RIED}

Even though the ceramics under study are not first-wall materials for a fusion reactor, they will be subjected to a considerable amount of radiation. For DEMO, the neutron irradiation is expected to generate up to 0.1-0.5 dpa in the materials. Because of the amount of radiation, there are some radiation induced effects that appear and modify the dielectric properties of the ceramics.

Radiation Induced Conductivity (RIC) is an increase of the electrical conductivity due to the radiation induced excitation of electrons from the valence band to the conduction band. This effect is flux dependent and it is a temporary effect present while the material is under ionizing radiation; it doesn't create permanent material damage. Different factors such as temperature, ionizing radiation dose rate and material impurity content determine its magnitude [5]. The theoretical aspects of RIC are well understood but it is hard to predict for a specific grade material. Thus, RIC analysis in ceramics requires detailed experimental characterization $[6,7]$.

Radiation Induced Electrical Degradation (RIED) is an increase of the volume electrical conductivity due to the radiation-induced defects in the presence of an electric field. Contrary to RIC, RIED is a permanent effect on the material after irradiation and it poses a bigger problem, not only because it increases the conductivity above RIC, but also because the theory behind this type of degradation is not yet fully understood. It is not clear if RIED is entirely a real volume degradation, as it is very difficult to experimentally separate surface and volume conductivities. Different factors such as electrical field, total dose, dose rate, temperature, radiation source and spectrum, material type and irradiation environment can influence the magnitude of the effect $[8,9]$.

In order to test both RIC and RIED in the alumina ceramics of interest, a comprehensive irradiation plan has to be developed taking into account all the factors that influence these mechanisms. However, before going into the irradiation phase, it is crucial to have the materials fully characterized and selected prior to the irradiation, since the extent of radiation induced effects will be determined by the comparison between pre and post-irradiated materials. The dielectric 
characterization of the alumina ceramics before irradiation is the topic that will be treated here.

\section{EXPERIMENTAL SET-UP}

The dielectric properties of the samples under test have been characterized by two different resonant methods. The measurements have been carried out at room temperature. The test methods and the equipment used for the lower frequency spectrum are different from those used in the higher frequency spectrum $(>300 \mathrm{MHz})$ because, at lower frequencies, the test sample behaves as a lumped circuit element. However, at higher frequencies, the sample exhibits a distributed parameter behaviour since its physical dimensions become of the same order of the electrical field.

\section{DPMS OPEN RESONATOR (10 KHZ- $100 \mathrm{MHZ})$}

For frequencies from $10 \mathrm{kHz}$ to $100 \mathrm{MHz}$, the half-power-gap variation resonant method has been used. This is a technique that consists of measuring the response of a resonant circuit when the sample is placed between the parallel plates of a condenser and then comparing it with the same measurement without the sample [10]. These measurements are made using the DPMS1000 , a commercial system from Japan-J\&M (see Fig. 1). One of the advantages of this system is that the resonant LCR circuit is fitted into a plug-in module made ad-hoc for different pre-set frequencies. This allows the user to easily change the entire circuit to have a completely custom-made system for each frequency. Another advantage of the system is that it provides good accuracy for very low losses. It can measure loss tangent values up to $3 \times 10^{-6}$ with a precision of $\pm\left(3 \times 10^{-6}+0.5 \%\right)$ and permittivity better than $5 \%$ [3]. Since the DPMS is parallel plate capacitor equipment, the accuracy of the measurements is limited by the precision obtained in the sample thickness. For accurately parallel-polished samples, changes as low as $0.3 \%$ in the measurement of permittivity can be noticed. The measurements are carried out in an $\mathrm{N}_{2}$ controlled atmosphere to avoid moisture since it has been demonstrated that humidity influences the dielectric losses on alumina [11].

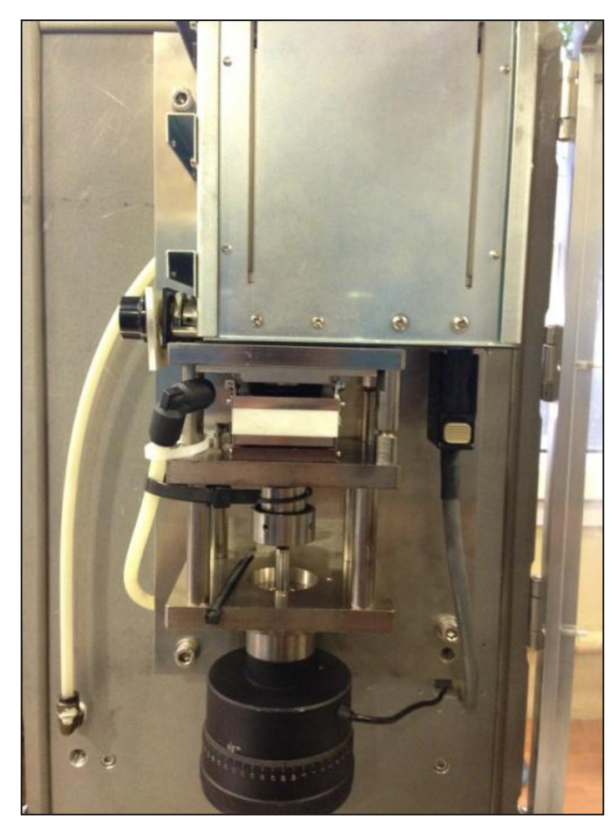

Fig. 1. DPMS commercial system from Japan-J\&M. CIEMAT

\section{Cylindrical Resonant Cavity (12 GHz)}

For higher frequencies, specifically at $12 \mathrm{GHz}$, a closed cylindrical resonant cavity was used (see Fig. 2). This is also a resonant method where the dielectric properties of the sample are obtained by comparison of the resonance characteristics with and without the sample inside of the cavity. The use of resonance cavities for the characterization of dielectric properties of insulating materials using microwaves is an established technique [12]. For measuring disk-shaped samples using TE modes, the sample is placed against one

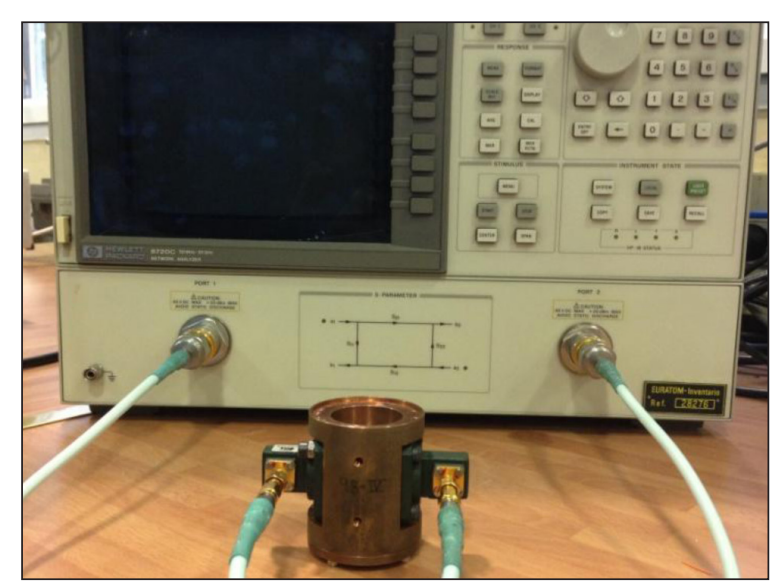

Fig. 2. Cylindrical resonant cavity (without the top plate) connected to a vector analyser. CIEMAT 
of the cavity end plates. The sample diameter has to be equal to the cavity diameter. However, this method has some setbacks. First of all, there is a thin air gap between the sample and the bottom plate that disturbs the electromagnetic field and gives rise to a systematic error in the calculation of the permittivity and $\tan \delta[13,14]$. This error can be neglected for thick samples but for $1 \mathrm{~mm}$ samples, sample thickness usually used for the DPMS, it can reach values of around a few tens per cent. A correction factor could be included in the permittivity and $\tan \delta$ equations [13] if the thin air gap size was known. It has been recommended [13] to approximate this value to ten times the roughness of the sample. But even with this approximation, an unknown error would exist and it will increase with decreasing sample size.

Another setback is that for sample sizes smaller than half the wavelength of the TE field, the resonator is insensitive to changes in the sample permittivity and it forces a very high lower limit on the measurable $\tan \delta$, which is incompatible for the low-loss materials of interest. This effect arises from the fact that the electric field vanishes at the metallic walls of the cavity. Therefore, if a very thin sample is placed against the end plate, the electric field is very low within the sample and measurement sensitivity is lost.

These issues have been solved at CIEMAT by developing a special measuring technique [15]. It is based on raising the sample through parallel-pol- ished silica supports inside the cavity in order to move it away from the field minimum. In this case, a new region must be considered in the analysis of the resonator. Therefore, the traditional two-dielectric-region cavity approach is no longer valid and Maxwell equations and boundary conditions are reformulated to analyse a cylindrical resonant cavity containing three dielectric regions.

With this modified system it is possible to determine $\tan \delta$ with an error less than $10 \%$ down to values of around $10^{-5}$ and the permittivity with an error less than $0.1 \%$ [3].

\section{RESULTS}

A set of 2 different alumina types was developed by an industrial partner (Nanoker). A new self-doping production method was used to produce the initial powder. It consists of self-doping with nanoparticles to achieve good sintering without using additives like magnesia. Each powder has a slightly different element concentration but the main difference between them is the nanoparticles size $(0.40 \mu \mathrm{m}$ for powder 001 and $0.14 \mu \mathrm{m}$ for powder 002$)$. The samples produced from the smaller grain size powder presented a lower $\tan \delta$ value for higher frequencies. Based on this result, a spray drying process was added to the production of 002 powder samples to see the difference in the final dielectric loss. Spray drying consists of rapidly drying with a hot gas to produce dry powder from slurry. Figure 3 shows

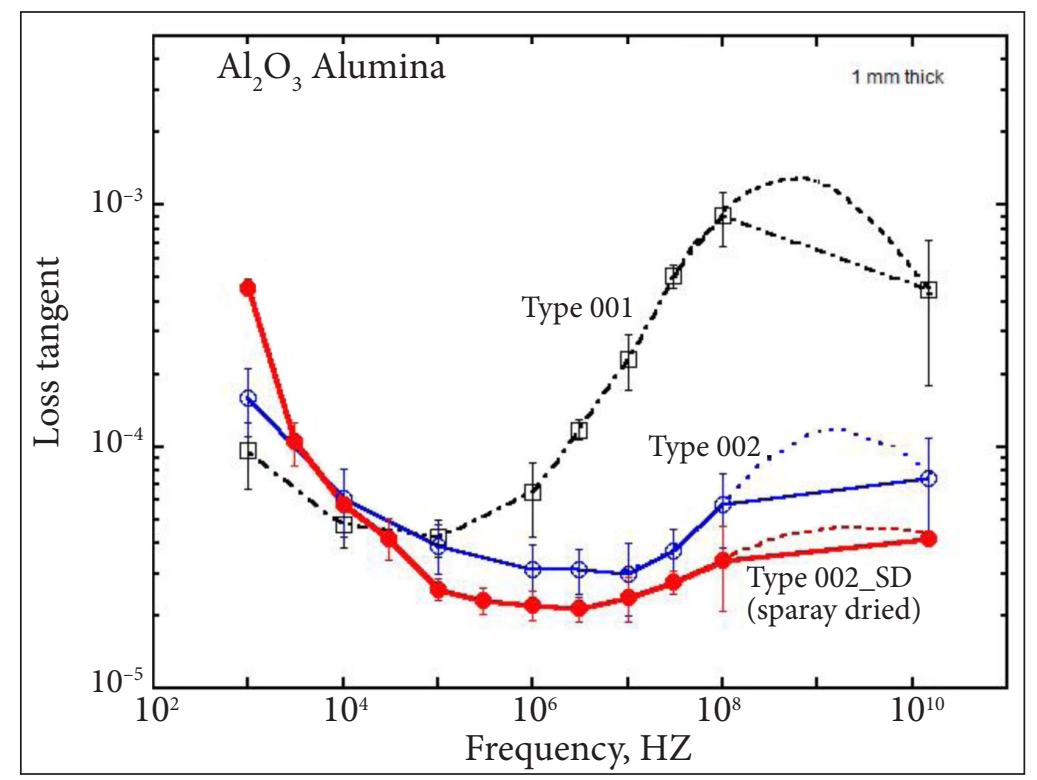

Fig. 3. Tan $\delta$ values for 3 different types of alumina. Type 001 has powder grain size of $0.40 \mu \mathrm{m}$. Type 002 has powder grain size of $0.14 \mu \mathrm{m}$. Type 002_SD has an additional spray drying step during fabrication 


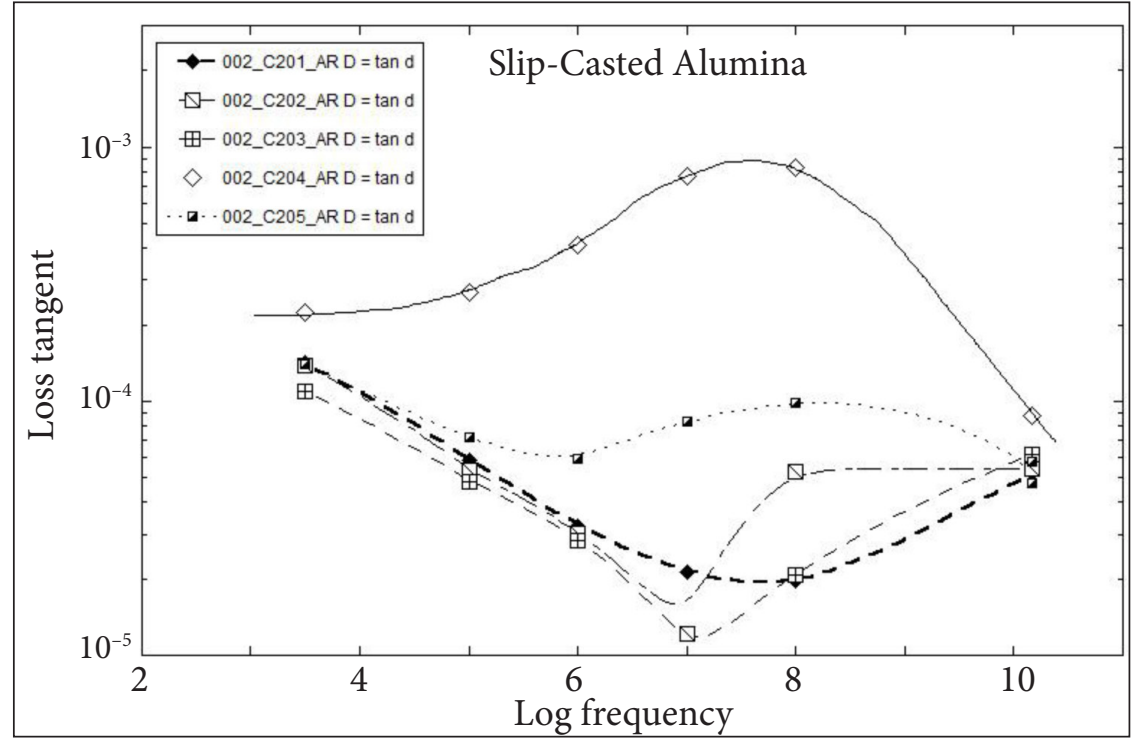

Fig. 4. Tan $\delta$ values of 5 slip-casted samples. All samples are cut from the same single rod of bulk material

the obtained results of these three different types of alumina in the whole frequency range.

Since different commercial production routes have to be tested in the search of a standardized production route, a slip-casting process was introduced to manufacture ceramics from powder 002. A slip, a suspension of fine raw materials powder in a liquid, is poured into a plaster mould that draws water from the poured slip to compact and form the casting. When it is dry, the solid clay can then be removed and sintered at high temperature.

In Fig. 4, it can be seen that even if the $\tan \delta$ values of the casted samples are in the desired low range, they are very different among the samples. Since the samples are cut from a single piece of material, it becomes clear that the dielectric properties are very inhomogeneous in the material and that this method is not capable of producing ceramics with reproducible dielectric properties. The reason can be a different amount of impurities, isolated or in clusters, or even a different shape/orientation of these inclusions [16].

\section{CONCLUSIONS}

The dielectric properties of the ceramic materials of interest were precisely measured using two different resonant techniques that cover the wide range of working frequencies in fusion applications and also provide the most accurate results for low loss materials. Results revealed that depending on the type of material and the manufacturing route, ceramics have better performance at different frequency ranges. Besides, some routes presented quite different deviations in the measured dielectric loss between samples from the same batch. Uniformity in the loss tangent values is also a key parameter when choosing the best manufacturing process in order to obtain a reference material. Therefore, assuring the reproducibility of the samples has become the next goal. In order to reach this goal, other samples produced by the industry using alternative manufacturing routes are currently being tested at CIEMAT.

\section{ACKNOWLEDGEMENTS}

This work has been supported by the MEIC Project (Ministerio de Economía, Industria y Competitividad) (ENE2015-70300-C3-1-R), TechnoFusión Project (S2013/MAE-2745) of the CAM (Comunidad Autónoma Madrid) and partially by the European Commission within the framework of the EUROfusion Consortium - WPMAT-FM project. The views and opinions expressed herein do not necessarily reflect those of the European Commission.

Received 1 March 2017 Accepted 15 May 2017 


\section{References}

1. Vila R., Gonzalez M., et al. The role of C-impurities in alumina dielectrics. Journal of the European Ceramic Society. 2004. Vol. 24. No. 6. P. 15131516.

2. Molla J., Heidinger R., Ibarra A. Alumina ceramics for heating systems. Journal of Nuclear Materials. 1994. Vol. 212-215. P. 1029-1034.

3. Vila R., Gonzalez M., et al. Dielectric spectroscopy of alumina ceramics over a wide frequency range. Journal of Nuclear Materials. 1998. Vol. 253. No. 1. P. 141-148.

4. Rovner L., Hopkins G. Ceramic materials for fusion. Journal of Nuclear Materials. 1976. Vol. 29. No. 3. P. 274-302.

5. Decreton M., Shikama T., Hodgson E. Performance of functional materials and components in a fusion reactor. Journal of Nuclear Materials. 2004. Vol. 329-333. P. 125-132.

6. Klaffky R., Rose B., et al. Radiation-induced conductivity of $\mathrm{Al}_{2} \mathrm{O}_{3}$ : Experiment and theory. Physical Review Letters. 1980. Vol. 21. No. 21. P. 3610.

7. Hodgson E., Clement S. The effect of iron on the radiation induced conductivity in gammaand electron-irradiated MgO. Journal of Radiation Effects. 1986. Vol. 97. No. 3-4. P. 251-256.

8. Hodgson E. Challenges for insulating materials in fusion applications. Nuclear Instruments and Methods in Physics Research B. 2002. Vol. 191. P. 744-751.
9. Shikama T., Zinkle S. Long term degradation of electrical insulation of $\mathrm{Al}_{2} \mathrm{O}_{3}$ under high flux fission reactor irradiation. Journal of Nuclear Materials. 1998. Vol. 258-263. P. 1861-1866.

10. Kakimoto A., Etoh A., et al. Precise measurement of dielectric properties at frequencies from $1 \mathrm{kHz}$ to $100 \mathrm{MHz}$. Review of Scientific Instruments. 1987. Vol. 58. No. 2. P. 269-275.

11. Molla J., Gonzalez M., et al. Effect of humidity on microwave dielectric losses of porous alumina. Journal of Applied Physics. 1999. Vol. 85. No. 3. P. 1727-1730.

12. Horner F., Taylor T., et al. Resonance methods of dielectric measurement at centimetre wavelengths. Journal of the Institution of Electrical Engineers III. 1999. Vol. 93. P. 53-68.

13. Burdun G., Zal'tsman E., et al. Methods for raising precision in measuring the characteristics of dielectrics at ultrahigh frequencies. Measurement Techniques. 1969. Vol. 5. P. 682-687.

14. Zal'tsman E. Permittivity measurement error due to a residual gap. Measurement Techniques. 1968. Vol. 11. P. 1516-1519.

15. Molla J. A dielectric property measurement system for thin samples based on a resonant cavity with three dielectric regions. Measurement Science and Technology. 2001. Vol. 13. No. 1. P. 5058.

16. Vila R., Jimenez de castro M. Thermally stimulated depolarization of ellipsoidal particles in an insulating medium. Journal of Physics D Applied Physics. 1992. Vol. 25. P. 1357. 
Darío Cruz, Rafael Vila, Begoña Gómez-Ferrer

\section{ALIUMINIO KERAMIKOS DIELEKTRINIŲ SAVYBIŲ TAIKYMAS BRANDUOLIŲ SINTEZE்JE}

\section{Santrauka}

Izoliacinès medžiagos, skirtos radijo bangų dažnių langui, ịvairioms antenoms, šildymo sistemoms ir kai kurioms diagnozavimo sistemoms, vis dar laikomos iššūkiu ateities sintezès jègainèse, tokiose kaip DEMO. Tam tikslui aliuminio oksido keramika $\left(\mathrm{Al}_{2} \mathrm{O}_{3}\right)$ yra viena iš pagrindinių kandidačių. Galios praradimus lemia dielektrinès medžiagos savybės, pavyzdžiui, dielektrinè skvarba $(\varepsilon)$ ir nuostolių kampo tangentas $(\tan \delta)$. Todèl $\tan \delta$ vertès privalo būti kuo mažesnès (nuo $10^{-6}$ iki $10^{-3}$, priklausomai nuo taikymo srities). Gamybos procesas iš esmès lemia gautos medžiagos dielektrines savybes, todèl būtina nustatyti ir patvirtinti standartini gamybos metodą, kuris užtikrintų, kad gauta keraminè medžiaga, skirta būsimoms sintezès jègainèms, turi vienodas ir standartizuotas dielektrines savybes.
Šios keraminès medžiagos bus eksploatuojamos ekstremaliomis sąlygomis DEMO jejgainèje, jos bus veikiamos dideliu neutroninès apšvitos srautu. Spinduliuotès sukeltas laidumas ir elektrinė degradacija yra reiškiniai, darantys didžiausią ịtaką medžiagų dielektrinèms charakteristikoms, todèl pradžioje jos turi būti išbandytos esant atitinkamoms apšvitos sąlygoms. Taigi svarbu tiksliai nustatyti keraminių medžiagų dielektrines savybes dar prieš apšvitinimą, kad būtų galima jas palyginti su charakteristikomis, gautomis po neutronų apšvitos. Be to, kiti spinduliuotès tipai, pavyzdžiui, beta ir gama, taip pat naudojami siekiant gauti daugiau informacijos apie keramikos dielektrinių savybių priklausomybę nuo spinduliuotés poveikio.

Darbe pateiktos anksčiau apšvitintų medžiagu nuostolių kampo tangento ir dielektrinès skvarbos vertès, naudota CIEMAT matavimo metodika. Šių metodų privalumai - labai platus dažnių diapazonas (nuo $\mathrm{kHz}$ iki GHz), reikalingas aliuminio oksido pritaikymui sintezès jègainèje, ir geriausias tikslumas siekiant kuo mažesnių nuostolių.

Raktažodžiai: sintezé, DEMO, keramika, dielektrinès savybės, apšvitinimas 